\title{
Intraspecific differences in metabolic rate of Chroeomys olivaceus (Rodentia: Muridae): the effect of thermal acclimation in arid and mesic habitats
}

\author{
Diferencias intraespecíficas en la tasa metabólica de Chroeomys olivaceus (Rodentia: \\ Muridae): efecto de la aclimatación térmica en hábitat áridos y mésicos
}

\author{
F. FERNANDO NOVOA ${ }^{3}$, ANTONIO RIVERA-HUTINEL ${ }^{2}$, \\ MARIO ROSENMANN ${ }^{1} \&$ PABLO SABAT ${ }^{1,2}$
}

\author{
${ }^{1}$ Departamento de Ciencias Ecológicas, Facultad de Ciencias, Universidad de Chile, Casilla 653, Santiago, Chile \\ ${ }^{2}$ Center for Advanced Studies in Ecology \& Biodiversity and Departamento de Ecología, Facultad de Ciencias Biológicas, \\ Pontificia Universidad Católica de Chile, Santiago-Chile \\ ${ }^{3}$ Centro de Ecología Aplicada Limitada, Avenida Suecia 3304, Santiago, Chile \\ *e-mail of corresponding author: fnovoa@cea.cl
}

\begin{abstract}
Studies of metabolic capacities in rodents have been largely studied at an inter-specific levels, but physiological capacities of populations belonging to the same species have received lesser attention. Here we studied the maximum and basal metabolic rates of two populations of the rodent Chroeomys olivaceus dwelling in habitats with contrasting temperature and rainfall regimes, and to test if differences in metabolic capacities are due to local adaptation or acclimatization effect. After four weeks of acclimation to 25 and $10^{\circ} \mathrm{C}$, the BMR and MMR were determined in individuals from the northern population of Caleta Loa, and the southern population of La Picada. Individuals from 'La Picada' population were heavier than those from Caleta Loa. MMR and BMR exhibited higher values in cold acclimated animals compared with warm-acclimated animals. Besides, BMR, but not MMR, was lower in Caleta Loa individuals, in spite of the acclimation treatment. Hence, the differences in the metabolic capacities and the response to acclimation of $C$. olivaceus populations appear to be an evolutionary response to the environmental cues.
\end{abstract}

Key words: basal metabolic rate, Chroeomys olivaceus, maximum metabolic rate, population, phenotypic plasticity.

\section{RESUMEN}

Las capacidades metabólicas en roedores han sido ampliamente estudiadas en un nivel ínterespecífico, pero los atributos fisiológicos de las poblaciones que pertenecen a una misma especie, han recibido menos atención. Aquí estudiamos las tasas metabólicas máximas y basales de dos poblaciones del roedor Chroeomys olivaceus que viven en habitats con temperaturas y regímenes de precipitaciones contrastantes y se analiza si las diferencias en las capacidades metabólicas se deben a diferenciación local o a efectos de aclimatación. Después de cuatro semanas de aclimatación a 25 y $10^{\circ} \mathrm{C}$, el BMR y MMR fueron determinados en individuos de la población norteña de Caleta Loa y en la población sureña de "La Picada". Los individuos de la población "La Picada" presentaron mayor masa corporal que los de Caleta Loa. Los valores de MMR y BMR fueron más altos en animales aclimatados al frío, comparados con los aclimatados a temperaturas más cálidas. Asimismo, solo BMR y no MMR, fue más bajo en los individuos de Caleta Loa, a pesar del tratamiento de aclimatación. Por lo tanto, las diferencias en las capacidades metabólicas y en la respuesta a la aclimatación de las poblaciones de C. olivaceus, parecen ser una respuesta evolutiva a las claves ambientales.

Palabras clave: tasa metabólica basal, Chreomys olivaceus, tasa metabólica máxima, población, plasticidad fenotípica.

\section{INTRODUCTION}

The influences of climate on the metabolic capacities and its ecological consequences have been one of the main topics studied by evolutionary physiologist (McNab 2002). Maximum and basal metabolic rates of endotherms (MMR and BMR) determines the 
survival of the animals in extreme situations, in desert and cold habitats, and represent key factors determining the limits of of distribution of endotherms (Rosenmann \& Morrison 1974; Bozinovic \& Rosenmann 1989, Tieleman et al. 2002, Tieleman et al. 2003). Studies of metabolic capacities in rodents have been largely addressed at interspecific levels, revealing that several factors such as body mass, food habits, activity, climate and phylogeny are important predictors. For example, in a recent and integrative study Rezende et al. (2004) showed a significant effect of climate on both BMR and MMR after controlling by the effect of phylogeny. Besides, the effects of latitude and temperature on physiological capacities of populations belonging to the same species have begun to receive considerable attention in the last decade (Hayes 1989a, 1989b, Bozinovic et al 1999, Bacigalupe et al. 2004).

Recently studies included those that attempt to eliminate the historic bias incorporating phylogenetic adjustments assumes, often erroneously, that physiology is invariant (Garland et al. 1992). Nevertheless, the phenotypic plasticity exhibited by thermogenic capacities in endotherms suggest that a necessary caution must be taken when interpreting physiological differences between species or populations. Phenotypic plasticity, the ability to change and modify the phenotype in response to environment cues, is crucial for maintaining homeostasis under changing environments (Stearns 1989, Pigliucci 2001) and has been demonstrated occurrence in response to seasonal variations (Rosenmann et al. 1975, Wickler 1981, Bozinovic et al. 1990) and in the in experiments of thermal acclimatization in laboratory in several mammals species (Nespolo \& Rosenmann 1997, Nespolo et al. 2002). Hence, due to animals have adapted temporary and geographically to live in thermally variable environments by genetic, phenotypic or both physiological variation (Crawford \& Powers 1990, Bozinovic et al. 1999, Nespolo et al. 2002), it is recommendable to reanalyze comparative studies that incorporate the intraindividual physiological flexibility (sensu Spicer \& Gaston 1999).
The objective of this study is to determine the maximum and basal metabolic rates of two populations of a rodent species dwelling in habitats with contrasting temperature and rainfall regimes, and to test (if any) differences in metabolic capacities are due to local adaptation or acclimatization effect. We selected Chroeomys olivaceus as our experimental model. This rodent presents one of the widest latitudinal distributions described for a Chilean cricetid rodent, ranging from the $23{ }^{\circ} \mathrm{C}$ until the $43{ }^{\circ} \mathrm{C}$ (Contreras 1990). This wide distribution ensure that populations are subjected to very different environmental variables including the northern localities with a fairly desert climate where precipitations are almost absent and thermal ranges are small, and the southern habitats with rather cold atmospheres, larger thermal ranges and more abundant precipitations (Di Castri \& Hajek 1976).

\section{MATERIAL AND METHODS}

\section{Animals}

Chroeomys olivaceus individuals from two different populations were captured. Caleta Loa in the Antofagasta region, northern Chile (23'29' S, 70'26' W) is an arid (mean annual precipitation $2.2 \mathrm{~mm}$., Di Castri \& Hajek 1976) and relatively warm locality (mean annual temperature $\left.17{ }^{\circ} \mathrm{C}\right)$, whereas La Picada in Osorno, southern Chile (23'29' S, 70'26' W) is a cold (mean annual temperature $10{ }^{\circ} \mathrm{C}$ ) and rainy locality (mean annual precipitation 1,659 mm, Di Castri \& Hajek 1976). Animals were captured in July 1999 at Caleta Loa and in January 2000 at La Picada with Sherman traps, and transported to laboratory and maintained at $22 \pm 2{ }^{\circ} \mathrm{C}, \mathrm{L}: \mathrm{D} 12: 12$ in separate cages of $30 \mathrm{x}$ $40 \times 40 \mathrm{~cm}$, with rabbit food pellets and water ad libitum. After $24 \mathrm{~h}$, animals were weighed with an electronic balance $( \pm 0.01 \mathrm{~g})$ and then each population was randomly assigned to one of two treatments: one group was maintained at $25{ }^{\circ} \mathrm{C} \pm 2 \mathrm{~L}: \mathrm{D} 12: 12$, and the second at $10{ }^{\circ} \mathrm{C}$, L:D 12:12 for three weeks. After the acclimation period, animals were weighed and their thermogenic capacities were determined. 


\section{Metabolic rate}

Maximum metabolic rate (MMR) and basal metabolic rate (BMR) were measured, using a modified closed-circuit automatic system, based on the manometric design of Morrison (1951). Ambient temperature was controlled ( \pm $0.1{ }^{\circ} \mathrm{C}$ ) with a thermo-regulated bath in which the metabolic chambers were submerged. BMR was determined at $\mathrm{T}_{\mathrm{a}}=30{ }^{\circ} \mathrm{C}$, which is within the thermoneutral zone for this species (Bozinovic \& Rosenmann 1988) and was calculated as the average of the two lowest values observed in two hours of metabolic trials. Measures were performed in postabsorptive individuals (more than five $\mathrm{h}$ after the last meal, see Nespolo et al. 2003) in their rest phase of activity. MMR was obtained at $\mathrm{T}_{\mathrm{a}}$ $=5{ }^{\circ} \mathrm{C}$, using mixtures of $80 \% \mathrm{He}$ and $20 \%$ $\mathrm{O}_{2}$, a four-fold more conductive medium than air that facilitates heat transfer (Rosenmann \& Morrison 1974).

The most appropriate analysis for biological variables with allometry is ANCOVA, using body mass as a covariate. However, because the exponent of the allometric relationship between body mass and BMR and MMR were not significantly different from 1 (exponent \pm $\mathrm{SE}=0.5 \pm 0.36, \mathrm{t}=1.39, \mathrm{P}>0.05$ for $\mathrm{BMR}$ and exponent $\pm \mathrm{SE}=0.45 \pm 0.25, \mathrm{t}=1.74, \mathrm{P}>$ 0.05 respectively), it is appropriate to compare mass-specific metabolic (i.e., $\mathrm{mL} \mathrm{O}_{2} \mathrm{~g}^{-1} \mathrm{~h}^{-1}$ ) rates between populations. Hence we also performed a two-way ANOVA using species and acclimation condition as factors to test the effects of locality and acclimation. In addition a posteriori Tukey test was performed to test for specific differences among treatments. All statistical comparisons were conducted using Statistica for Windows (1997). All data are reported as mean $\pm \mathrm{SD}$.

\section{RESULTS}

Body mass was significantly different between populations $\left(\mathrm{F}_{1,22}=37.17, \mathrm{P}<0.001\right)$ but was unaffected by acclimation $\left(\mathrm{F}_{1,22}=0.02, \mathrm{P}>\right.$ 0.87 ) nor by the interaction of both factors $\left(\mathrm{F}_{1,22}=0.38, \mathrm{P}>0.54\right)$. Body mass of our sample was $55 \%$ higher in the southern $(39.4 \pm$ $7.95 \mathrm{~g})$ than in the northern $(25.32 \pm 2.9 \mathrm{~g})$ population $\left(\mathrm{F}_{1,21}=32.18, \mathrm{P}<0.001\right)$.
The ANCOVA revealed a significant effect of acclimation temperature on total MMR $\left(\mathrm{F}_{1,22}\right.$ $=20.16, \mathrm{P}<0.001)$. In addition, a non significant effect of the locality $\left(\mathrm{F}_{1,21}=0.02, \mathrm{P}\right.$ $=0.88)$ nor the interaction of both factors $\left(F_{1,21}\right.$ $=0.02, \mathrm{P}=0.88)$ were found. Besides, the total BMR was affected by acclimation $\left(\mathrm{F}_{1,21}=4.82\right.$, $\mathrm{P}=0.04)$, and a marginal significance was found between localities $\left(\mathrm{F}_{1,21}=3.29, \mathrm{P}=\right.$ 0.08). However the a posteriori Tukey test revealed that in both treatments, animals from Caleta Loa exhibited lower total BMR than those from La Picada $(\mathrm{P}<0.001$ for both treatments). The analysis of variance using mass-specific metabolic rates revealed consistent results with those of ANCOVA. A significant differences in mass-specific MMR was found between cold-acclimated and warmacclimated animals $\left(\mathrm{F}_{1,22}=20.82, \mathrm{P}<0.001\right)$, but a non significant differences between both populations $\left(\mathrm{F}_{1,22}=3.73, \mathrm{p}>0.05\right)$. In addition, a non significant effect of the interaction between both factors on MMR was found $\left(\mathrm{F}_{1,22}\right.$ $=0.04, \mathrm{P}=0.83)$. In the Loa population massspecific MMR was $48.7 \%$ higher in the cold group (Tukey test, $\mathrm{P}<0.001$ ), whereas in the southern population was $70.3 \%$ higher in the cold than in the warm group (Tukey test, $\mathrm{P}<$ 0.001, Fig. 1). Mass-specific BMR was also significantly affected by acclimation temperature $\left(\mathrm{F}_{1,22}=4.32, \mathrm{P}=0.049\right)$, locality $\left(\mathrm{F}_{1,22}=4.83, \mathrm{P}=0.038\right)$ but not by the interaction between both factors $\left(\mathrm{F}_{1,22}=0.026, \mathrm{P}\right.$ $=0.87$ ). The Loa population showed an increase of $25 \%$ in cold acclimated animals (Tukey test, $\mathrm{P}<0.05)$, and in the southern population the increase was $17 \%$ but the Tukey test did not show statistical significance (Tukey test, $\mathrm{P}=$ $0.20)$. When analyzed by locality, the southern population exhibited a $20 \%$ higher massspecific BMR than the northern population (Tukey test, $\mathrm{P}=0.03$, Fig. 2). Accordingly, the additive aerobic scope (MMR-BMR) was significantly affected by acclimation temperature $\left(\mathrm{F}_{1,22}=20.15, \mathrm{P}<0.001\right)$ and was significantly higher in the Loa population $\left(\mathrm{F}_{1,22}\right.$ $=5.25, \mathrm{P}=0.031)$ than in southern population. No significant effect of the interaction of both factor was observed for this trait $\left(F_{1,22}=0.06, P\right.$ $=0.81)$. In addition, when all animals were pooled, a significant and positive association between total MMR and BMR was observed $\left(\mathrm{F}_{1,22}=12.37, \mathrm{P}=0.002\right.$, Fig. 3). 


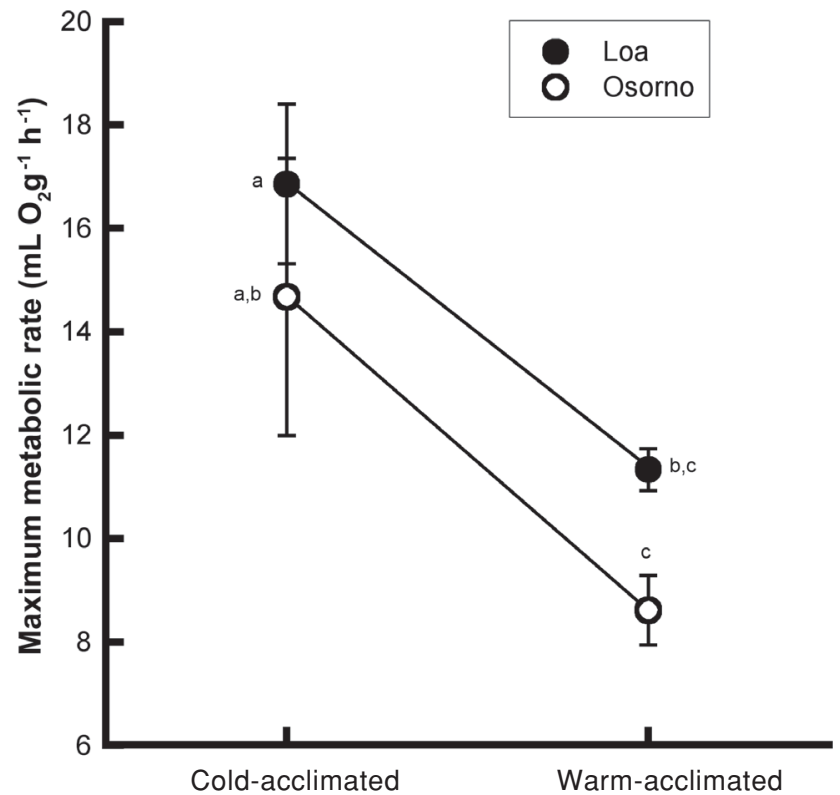

Fig. 1: Mass specific maximum metabolic rate (MMR) attained by two Chroeomys olivaceus populations acclimated either to warm $\left(30^{\circ} \mathrm{C}\right)$ or cold $\left(10^{\circ} \mathrm{C}\right)$ environments for 30 days. Values are shown as mean $\pm 1 \mathrm{SE}$. Similar letters denotes no significant differences $(\mathrm{P}>0.05)$ between means after the a posteriori Tukey test.

Metabolismo máximo masa específico (MMR) alcanzado por dos poblaciones de Chroeomys olivaceus aclimatados a un ambiente cálido $\left(30^{\circ} \mathrm{C}\right)$ y otro frío $\left(10^{\circ} \mathrm{C}\right)$ por 30 días. Los valores se muestran como promedio \pm 1 EE. Letras similares denotan ausencia de diferencias significativas $(\mathrm{P}>0,05)$ entre promedios después de una prueba a posteriori de Tukey.

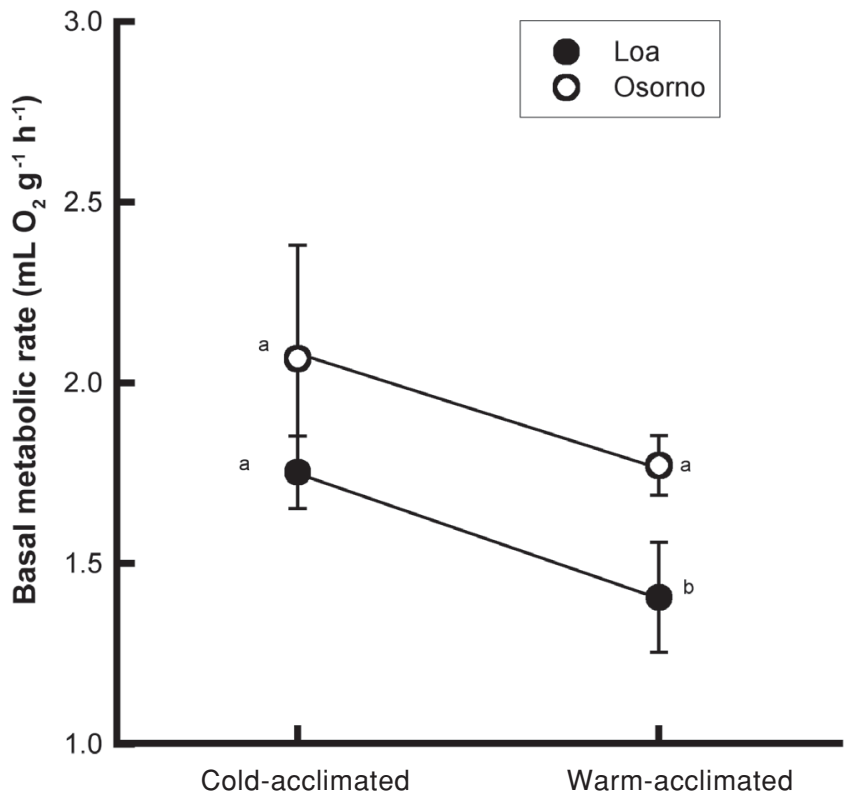

Fig. 2: Mass specific basal metabolic rate (BMR) attained by two Chroeomys olivaceus populations acclimated either to warm $\left(30^{\circ} \mathrm{C}\right)$ or cold $\left(10^{\circ} \mathrm{C}\right)$ environments for 30 days. Values are shown as mean \pm 1 SE. Similar letters denotes no significant differences $(P>0.05)$ between means after the a posteriori Tukey test.

Metabolismo basal masa específico (BMR) alcanzado por dos poblaciones de Chroeomys olivaceus aclimatados a un ambiente cálido $\left(30^{\circ} \mathrm{C}\right)$ y otro frío $\left(10^{\circ} \mathrm{C}\right)$ por 30 días. Los valores se muestran como promedio \pm 1 EE. Letras similares denotan ausencia de diferencias significativas $(\mathrm{P}>0,05)$ entre promedios después de una prueba a posteriori de Tukey. 


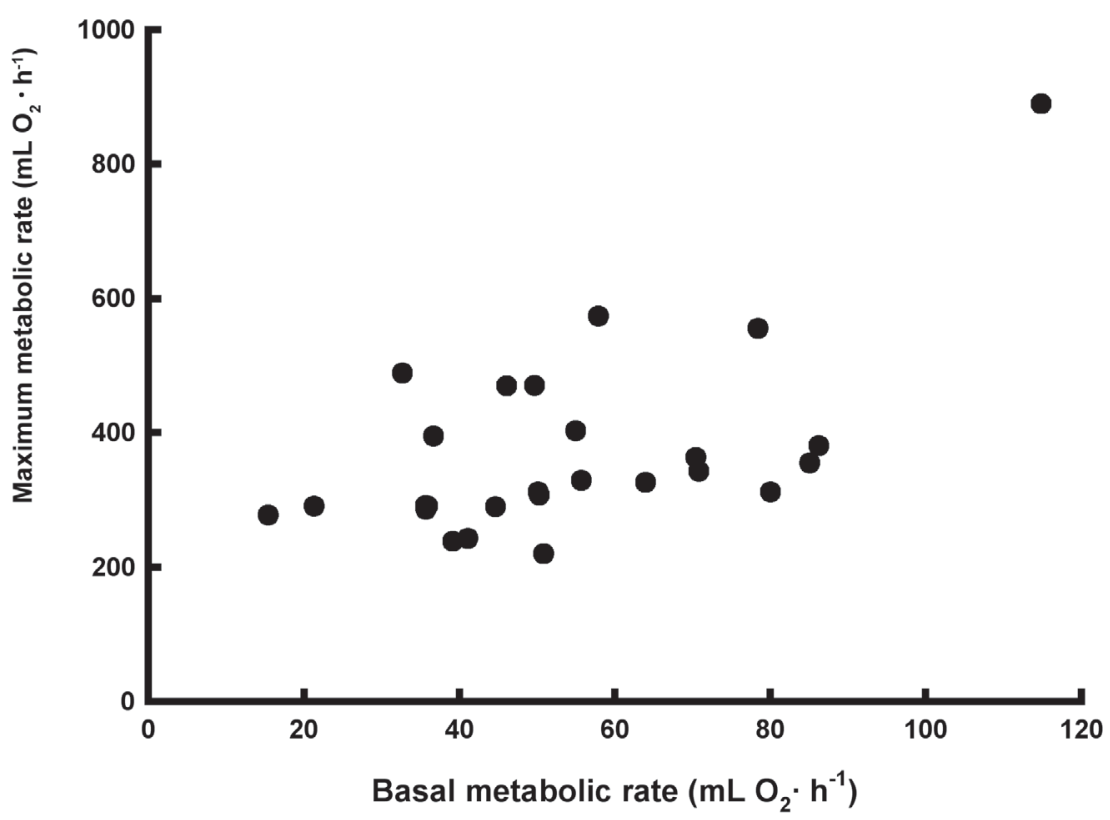

Fig. 3: Relationship between basal metabolic rate and maximum metabolic rate by two Chroeomys olivaceus populations. Plot was constructed by pooling all individuals from Loa and Osorno populations acclimated either to warm and cold conditions for 30 days.

Relación entre el metabolismo basal y el metabolismo máximo de dos poblaciones de Chroeomys olivaceus. El gráfico fue construido a partir de los datos en conjunto de los individuos de las poblaciones de Loa y Osorno aclimatados a condiciones de calor y frío por 30 días.

\section{DISCUSSION}

The major advantages of phenotypic plasticity come out from the fact that organisms may cope with fluctuating and unpredictable environments in an ecological time scale without involving changes in genotype (Stearns 1989) or micro evolutionary processes (Hansen \& Boonstra 2000). The increase in thermoregulatory maximum metabolic rate (MMR) by acclimatization in the field (and acclimation in laboratory) exhibited by $C$. olivaceus probably increases survival of natural populations during the cold season, or during short-term exposure to cold conditions (Hayes \& O'Connor 1999). This increase in MMR is believed to impose some costs associated to the maintenance of energetically expensive metabolic machinery, which are reflected in the high basal metabolic rate (BMR) of cold-acclimated animals compared with warm-acclimated animals (Konarzewski \& Diamond 1995). Although we found a positive association between MMR and $\mathrm{BMR}$, changes in BMR by acclimation are lesser pronounced than changes in MMR (Fig. 1 and 2). In this vein, Weibel et al. (2004), exploring the mechanism of determination of metabolic rate in mammals (BMR and MMR) suggested that both physiological variables are at some extent independent. Our results agree with those of Weibel et al (2004), and suggest that such a cost in energy expenditure, if does exist, is at least small. Besides, BMR increases after cold acclimation with respect to warm acclimation (Fig. 2), but to a low extent in the La Picada population. In this sense, it has been proposed that the ability to modify the phenotype in response to environmental cues might be higher in species or populations that experiences major changes in environmental variables (e.g., temperature) than those that rarely experienced extreme environment fluctuation (see Sabat et al. 2004, and references therein). We suspect that the lower thermal range experienced by the Caleta Loa population in respect to the La Picada population may explain differences in the magnitude of response of BMR to thermal acclimation.

Several studies have shown that at an interspecific level, the energy expenditure of mammals is well correlated to the ambient temperature of their natural habitats. Then, 
maximum metabolic rate and basal metabolic rate may determine the range of distribution of animals (McNab 1988, Bozinovic \& Rosenmann 1989) and may be useful information to predict the thermal environment that animals have experienced (Lovegrove 2003, Rezende et al. 2004). Although the reduction in BMR in desert climates has been reported elsewhere from interspecific studies, differences among population have received little attention. However, Mathias et al. (2004) have recently reported that Mus musculus from the desert island of Porto Santo exhibits a low BMR, representing only $56 \%$ of the predicted value based in body mass, whereas the more mesic population from mainland areas of Portugal exhibited a BMR closer to the expected value. In $C$. olivaceus BMR is closely related to the thermal environment in each population. In this way, individuals from the meridional and colder population (La Picada) exhibit higher values of mass-specific BMR than individuals from the septentrional population, in spite of the acclimation temperature, suggesting that differences in the overall basal metabolic rate exhibited by $C$. olivaceus can not be explained by acclimatization to different habitats (Fig. 2). A probable explanation for this phenomena may be related to the reduced energy expenditure exhibited by endotherms in warm regions. In this sense, Haim \& Izhaki (1995) comparing six rodent species from desert environments with six from mesic environments reported that those from desert had reduced resting metabolic rates which allow rodents to conserve energy and presumably water. Reduced resting and basal metabolic rates are characteristic features of both mammals and birds dwelling in desert habitats, which have been reported elsewhere at interspecific level (Degen et al 1998, Tieleman \& Williams 2000, Mueller \& Diamond 2001). We suspect that the reduction in BMR of $C$. olivaceus at the northern population may be an evolutionary response related to the water shortage, particularly in warmer season when environment temperatures rise, and hence, the evaporative water loss increases (Tieleman et al 1999). Therefore, the thermal environment and the low availability of water in those habitats (preformed in food and fresh water) appear to be main factors explaining differences found in
BMR among these populations. However, as pointed out by Mueller \& Diamond (2001), the proximal factor that may explain the relationship between climate (latitude, altitude, temperature and rainfall) and metabolic rates is the net primary productivity, which depends on factors described above. Indeed, in five rodent species of the genus Peromiscus from distant areas characterized by different rainfalls, BMR increases with net primary productivity, even though they were breed in the laboratory from a stock that have been held for more than 10 generations (Mueller \& Diamond 2001). Regarding our results, the heavier individuals from La Picada may be seen as an adaptation to different thermal regimens following the Bergman's rule, which states that body size correlates with latitude (cited in McNab 2002); but also as an effect of the resource availability which in turn correlates with latitude (see McNab 2002 for an extensive discussion). Because body mass of $C$. olivaceus was not affected by acclimation, population differences seem to be a rigid character shaped probably by temperature, productivity or both (see Hansen $\&$ Boonstra 2000 and references therein).

Several authors have reported increases in MMR in response to low environment temperatures (Rosenmann et al. 1975, Hayes 1989a, Bozinovic et al. 1990, Nespolo \& Rosenmann 1997). Simmilarly some studies reported interspecific differences in the acclimation response, which is related to the thermal variation in their distribution ranges and/or their original distribution (Nespolo et al. 2001). Our study revealed that $C$. olivaceus exhibited a strong effect of acclimation temperature, although the MMR remained constant between populations. The absence of differences in the magnitude and shape of the acclimation response of MMR between populations may also be seen as a consequence of a rigid endothermy (see McNab 1992). As pointed out by Bozinovic et al. (1999) some species of Abrothrix (a genera closely related to Chroeomys) in the Andean regions seems to exhibit this kind of fixed character in the thermoregulatory energetics, even though the species inhabit very different thermal environments. However an alternative explanation may be argued. It is well known that animals can extend their geographical ranges beyond their physiological capacities. 
The behavioral abilities of some rodents to choose microhabitats or to build nests (Bozinovic et al. 1988), indeed, may lead to a similar thermal environment, even among habitats with very different mean temperatures. In addition, recently Bozinovic et al. (2004) reported a lack of strong major shifts in total levels of daily energy expenditure in the diurnal rodent Octodon degus along the year. This was surprising, considering the thermal seasonality of their habitat. Indeed, their BMR remained unchanged along the year, and the field metabolic rate did not change in more than $20 \%$. Hence, the flexibility in the behavioral timing of activity allows rodents to maintain thermal homeostasis and energy balance throughout the year without major changes in energy expenditure (Kenagy et al. 2002).

In summary, we found that BMR and body mass differ between two population of $C$. olivaceus from two different thermal habitats. We also found that both BMR and MMR change by acclimation, situation that was expected in animals dwelling in seasonal habitats. In addition differences in BMR and body mass still remain after the acclimation to warm and cold condition in the laboratory, which suggest strongly the existence of local (genetic-based) differentiation. However we cannot exclude the effect of the developmental plasticity. Because the magnitude of the response to environment cues in some traits depends on the development stage of individuals, which is generally more pronounced in the first stages of their ontogeny (see Schlichting \& Pigliucci 1998, Pigliucci 2001), these population differences of $C$. olivaceus after acclimation may be due to differences in their thermal environment experienced during the ontogeny. Changes in metabolic rates may be due to both evolutionary and phenotypic adaptations. Our results do not allow us to decide between both phenomena, but as pointed out by Nespolo (2000) the response of thermogenic capacities to environmental cues might be flexible because the periodicity of the environmental changes. Hence, the differences in the metabolic capacities and the response to acclimation of C. Olivaceus populations' appear to be an evolutionary response to the environmental cues.

\section{ACKNOWLEDGMENTS}

This work was funded by FONDECYT grant No. 1980762 for F.F. Novoa. We thank Servicio Agícola y Ganadero (SAG) and Corporación Nacional Forestal (CONAF) for providing authorizations to capture animals. This paper was written with our dear professor Mario Rosenmann and is dedicated to his memory.

\section{LITERATURE CITED}

BACIGALUPE LD, RF NESPOLO, JC OPAZO \& F BOZINOVIC (2004) Phenotypic flexibility in a novel thermal environment: phylogenetic inertia in thermogenic capacity and evolutionary adaptation in organ size. Physiological and Biochemical Zoology 75: 805-815

BOZINOVIC F \& M ROSENMANN (1988) Comparative energetics of South American cricetid rodents. Comparative Biochemistry and Physiology 91A:195-202.

BOZINOVIC F \& M ROSENMANN (1989) Maximum metabolic rate of rodents: physiological and ecological consequences on distributional limits. Functional Ecology 3: 173-181.

BOZINOVIC F, M ROSENMANN \& C VELOSO (1988) Termorregulación conductual en Phyllotis darwini (Rodentia: Cricetidae): efecto de la temperatura ambiente, uso de nidos y agrupamiento social sobre el gasto de energía. Revista Chilena de Historia Natural 61: 81-86

BOZINOVIC F, FF NOVOA \& C VELOSO (1990) Seasonal changes in energy expenditure and digestive tract of Abrothrix andinus (Cricetidae) in the Andes range. Physiological Zoology 63: 12161231.

BOZINOVIC F, J LAGOS \& P MARQUET (1999) Geographic energetics of the Andean mouse Abrothrix andinus. Journal of Mamalogy 80: 205209.

CONTRERAS LC (1990) Cricetid species richness in the southern Andes: the effect of area. A critique of Caviedes and Iriarte (1989) Revista Chilena de Historia Natural 63: 19-22.

DEGEN AA, M KAM, IS KHOKHLOVA, BR KRASNOV \& TG BARRACLOUGH (1998) Average daily metabolic rate of rodents: habitat and dietary comparisons. Functional Ecology 12: 63-73.

DI CASTRI F \& ER HAJEK (1976) Bioclimatología de Chile. Ediciones Universidad Católica de Chile, Santiago, Chile. 129 pp.

GARLAND T JR, HARVEY PH \& AR IVES (1992) Procedures for the analysis of comparative data using phylogenetically independent contrast. Systematic Biology 41: 18-32.

HAIM A \& I IZHAKI (1995) Comparative physiology of thermoregulation in rodents: Adaptations to arid and mesic environments. Journal of Arid Environments 31: 431-440.

HANSEN TF \& R BOONSTRA (2000) The best in all possible worlds? A quantitative genetic study of geographic variation in the Meadow vole (Microtus pennsylvanicus). Oikos 89: 81-94 
HAYES JP (1989a) Field and maximal metabolic rates of deer mice (Peromyscus maniculatus) at low and high altitudes. Physiological Zoology 62: 732-744.

HAYES JP (1989b) Altitudinal and seasonal effects on aerobic metabolism of deer mice. Journal of Comparative Physiology 159B: 453-459.

HAYES JP \& CSO O'CONNOR (1999) Natural selection on thermogenic capacity of high-altitude deer mice. Evolution 53: 1280-1287.

KENAGY GJ, RF NESPOLO, RA VÁSQUEZ \& F BOZINOVIC (2002) Daily and seasonal limits of time and temperature on surface activity of degus. Revista Chilena de Historia Natural 75: 567-581.

KONARZEWSKI M \& J DIAMOND (1995) Evolution of basal metabolic rate and organ masses in laboratory mice. Evolution 49: 1239-1248.

LOVEGROVE BG (2003) The influence of climate on the basal metabolic rate of small mammals: a slow-fast metabolic continuum. Journal of Comparative Physiology B 173: 87-112.

MATHIAS ML, AC NUNES,CC MARQUES, I SOUSA, MG RAMALHINHO, JC AUFFRAY, J CATALAN \& J BRITTON-DAVIDIAN (2004) Adaptive energetics in house mice, Mus musculus domesticus, from the island of Porto Santo (Madeira archipelago, North Atlantic). Comparative Biochemistry and Physiology 137: 703-709.

MCNAB BK (1988) Complications inherent in scaling the basal rate of metabolism in mammals. Ecological Monographs 56: 1-19.

MCNAB BK (1992) The comparative energetics of rigid endothermy: the Arvicolidae. Journal of Zoology 227: 585-606.

MCNAB BK (2002) The physiological ecology of vertebrates. Cornell University Press, Ithaca, New York, USA. $576 \mathrm{pp}$.

MORRISON PR (1951) An automatic manometric respirometer. Review of Scientific Instruments 22: 264-267.

MUELLER P \& J DIAMOND (2001) Metabolic rate and environmental productivity: Well-provisioned animals evolved to run and idle fast. Proceedings of the National Academy of Sciences USA 98: 1255012554.

NESPOLO RF \& M ROSENMANN (1997) Historia térmica de roedores chilenos: una aproximación experimental. Revista Chilena de Historia Natural 70: $357-364$

NESPOLO RF (2000) Physiological performance, seasonality and phenotypic plasticity in small mammals: microevolution of change capacity in thermoregulatory characters. Revista Chilena de Historia Natural 73: 553-563.

NESPOLO RF, JC OPAZO \& F BOZINOVIC (2001) Thermal acclimation and non-shivering thermogenesis in three species of South American rodents: a comparison between arid and mesic habitats. Journal of Arid Environments 48: 581-590.

NESPOLO R, L BACIGALUPE, P SABAT \& F BOZINOVIC (2002) Interplay among energy metabolism, organ masses and digestive enzyme activity in the mouse-opossum Thylamis elegans: the role of thermal acclimation. Journal of Experimental Biology 205: 2697-2703.

NESPOLO R, L BACIGALUPE \& F BOZINOVIC (2003) The influence of heat increment of feeding on basal metabolic rate in Phyllotis darwini (Muridae). Comparative Biochemistry and Physiology A 134: 141-147.

PIGLIUCCI M (2001) Phenotypic plasticity: beyond nature and nurture. Johns Hopkins University Press, Baltimore, Maryland, USA.315 pp.

REZENDE EL, F BOZINOVIC \& T GARLAND JR (2004). Climatic adaptation and the evolution of basal and maximum rates of metabolism in rodents. Evolution: 1361-1474

ROSENMANN M \& P MORRISON (1974) Maximum oxygen consumption and heat loss facilitation in small homeotherms by He-O 2 . American Journal of Physiology 226: 490-495.

ROSENMANN M,P MORRISON \& D FEIST (1975) Seasonal changes in the metabolic capacity of redbacked voles. Physiological Zoology 48: 303-310.

SABAT P, K MALDONADO, A RIVERA-HUTINEL \& G FARFAN (2004) Coping with salt without salt glands: osmoregulatory plasticity in three species of coastal songbirds of genus Cinclodes (Passeriformes: Furnariidae). Journal of Comparative Physiology B 174: 415-420.

SCHLICHTING, CD \& M PIGLICCI (1998) Phenotypic evolution: a reaction norm perspective. Sinauer Associates, Sunderland, Massachusetts, USA. 387 pp.

SPICER JI \& KJ GASTON (1999) Physiological diversity and its ecological implications. Blackwell Science, Oxford, United Kingdom. 241 pp.

STATISTICA (1997) STATISTICA (Quick Reference) for the Windows 95 operating system. StatSoft, Inc., Tulsa, Oklahoma, USA.

STEARNS C (1989) The evolutionary significance of phenotypic plasticity. Bioscience 39: 436-445.

TIELEMAN BR, JB WILLIAMS, G MICHAELI \& B PINSHOW (1999) The role of the nasal passages in the water economy of crested larks and desert larks. Physiological and Biochemical Zoology 72: 219-226.

TIELEMAN BI \& JB WILLIAMS (2002b) Cutaneous and respiratory water loss in larks from arid and mesic environments. Physiological and Biochemical Zoology 75: 590-599.

TIELEMAN BI, JB WILLIAMS \& MB BUSCHUR (2002) Physiological adjustments to arid and mesic environments in larks (Alaudidae) Physiological and Biochemical Zoology 75: 305-313.

TIELEMAN BI, JB WILLIAMS \& P BLOOMER (2003) Adaptation of metabolism and evaporative water loss along an aridity gradient. Proceedings of the Royal Society of London 270: 207-214

WEIBEL ER, LD BACIGALUPE, B SCHMITT \& H HOPPELER (2004) Allometric scaling of maximal metabolic rate in mammals: muscle aerobic capacity as determinant factor. Respiratory Physiology and Neurobiology 140: 115-132.

WICKLER SJ (1981) Seasonal changes in enzymes of aerobic heat production in the white-footed mouse. American Journal Physiology 240: R289-R294. 